\title{
Effectivity of Asynchronous Learning on Theoretical Compared to Theoretical-Practical Courses at Film Department Universitas Multimedia Nusantara
}

\author{
Annita $^{1}$, Yosef Budi Susanto ${ }^{2}$ \\ ${ }^{1}$ Film Department, Universitas Multimedia Nusantara \\ ${ }^{2}$ Graduate Program in Management of Technology, Universitas Multimedia Nusantara \\ E-mail: ${ }^{1}$ annita@umn.ac.id, ${ }^{2}$ bsusanto@umn.ac.id
}

\begin{abstract}
Implementation of the e-learning method is a necessity, both synchronous and asynchronous modes. Universitas Multimedia Nusantara (UMN) encourages all of its study programs to implement both synchronous and asynchronous. Meanwhile, there are two types, of course, theoretical and theoretical-practical courses. Due to the specific nature of its learning process, the effectiveness of asynchronous learning is not yet proven. This research aims to evaluate implementing the asynchronous method on theoretical and practical courses at Film Department, UMN. The research was done quantitatively, using descriptive analysis and comparative test method, involving two hundred ninety-five respondents who participated in the study by filling questionnaires. The evaluation was done on the effectiveness of seven courses categorized into two types: theoretical and theoretical-practical courses. The results indicate that the implementation of asynchronous e-learning on seven courses is effective. Furthermore, there is no significant difference between the implementation of asynchronous elearning on theoretical and theoretical-practical courses. Based on this study, it is recommended that lecturers who apply asynchronous learning in their classes be more active in responding to the students. Challenging activities can also be added to make the discussion forum more active.
\end{abstract}

Keywords: effectivity, asynchronous, online learning

Efektivitas Pembelajaran Asynchronous pada Mata Kuliah Teori dan Praktik di Prodi Film Universitas Multimedia Nusantara

\begin{abstract}
Abstrak
Penerapan metode e-learning merupakan suatu kebutuhan, baik berbentuk sinkron maupun asinkron. Universitas Multimedia Nusantara (UMN) mendorong seluruh program studinya untuk menerapkan kedua bentuk e-learning ini. Sementara itu, ada dua jenis mata kuliah, teori dan praktik. Karena sifat spesifik dari proses pembelajarannya, efektivitas pembelajaran asinkron belum terbukti. Penelitian ini bertujuan untuk mengevaluasi efektivitas penerapan metode asinkron pada mata kuliah teori dan praktik di Prodi Film UMN. Penelitian ini dilakukan secara kuantitatif, menggunakan metode analisis deskriptif dan uji komparatif, dengan melibatkan dua ratus sembilan puluh lima responden yang berpartisipasi dalam penelitian dengan mengisi kuesioner. Evaluasi dilakukan terhadap efektivitas tujuh mata kuliah yang dikategorikan menjadi dua jenis, yaitu teori dan praktik. Hasil penelitian menunjukkan bahwa penerapan e-learning asynchronous pada tujuh mata kuliah sudah efektif. Tidak terdapat perbedaan yang signifikan antara penerapan e-learning asinkron pada mata kuliah teori dan praktik. Berdasarkan penelitian ini, disarankan agar dosen yang menerapkan pembelajaran asinkron di kelasnya lebih aktif dalam merespon
\end{abstract}


mahasiswa. Kegiatan yang menarik juga dapat ditambahkan untuk membuat forum diskusi lebih aktif.

Kata kunci: efektivitas, asinkron, pembelajaran online

\section{INTRODUCTION}

The pandemic has shaken education around the world. Many parties are concerned about its impacts on students, such as lengthening graduation and shattering their academic plans (Kasar et al., 2021; Onyema et al., 2020). The longterm effect of the overnight change to distance learning is also daunting. Inequality in education due to insufficient resources (Giatman et al., 2020) and proper implementation may lead to a bigger problem in the future (Murat \& Bonacini, 2020). Distance learning has been forced to be the solution to this problem. Schools and universities migrated to the online platform weeks after the outbreaks (Bao, 2020; Rajhans et al., 2020; UNESCO, 2020).

Like other educational institutions, Universitas Multimedia Nusantara (UMN) has altered to an online platform to cater to students' learning needs. Training on how to use the Learning Management System (LMS) and improvement on the system have been done continuously. At the Film Department, the adjustment to online learning is a challenge due to the nature of the study that requires film production (Annita, 2020). The department implements synchronous and asynchronous learning. The synchronous delivered through Zoom fulfils the social interaction among students and lecturers (McBrien et al., 2009). Meanwhile, the asynchronous is served through the university Moodle-based LMS. The LMS permits various learning media to be utilized in an integrated way in the learning process (Saputro \& Susilowati, 2019; Schwartz et al., 2020)

The asynchronous activities applied by UMN strictly follow PEDATI (Chaeruman, 2017). PEDATI stands for: PElajari (learn), DAlami (comprehend), Terapkan (apply), and EvaluasI (evaluate). The materials designed by the Film Department and the E-learning team include teaching videos, slides, quizzes, discussion forums, and assignments (Annita, 2020). After two years of implementation in the department, this paper aims to analyze the effectiveness of asynchronous teaching at the Film Department UMN. The asynchronous is applied in theory-based and combination of theory and practice-based courses. The researchers will examine the effectivity of the asynchronous through several components: materials, video, assignments, quizzes, interaction, learning duration, overall asynchronous learning. This research elaborates the author's previous research on the students' perception of asynchronous learning (Annita, 2020). 


\section{MATERIALS AND METHOD}

Researchers collected data for this study through questionnaires distributed at the end of the even semester of the 2020/2021 academic year. The study uses a 5-point Likert scale which ranges from strongly disagree (1), disagree (2), neutral (3), agree (4), and strongly agree (5). Questionnaires were distributed to the third and fifth-year students of the Film Department who have taken these courses, which were offered in the even semester of 2020/2021 academic year:

Table 1. Courses that implement asynchronous

\begin{tabular}{ll}
\hline \multicolumn{1}{c}{ Courses } & \multicolumn{1}{c}{ Type } \\
\hline Film Marketing & Theory \\
Image and Sound Concept & Theory \\
Introduction to Creative Business & Theory \\
Acting For Directors & Theory + Practice \\
Camera and Sound Recording & Theory + Practice \\
Experimental Film and Animation & Theory + Practice \\
Voice Acting & Theory + Practice \\
\hline
\end{tabular}

Asynchronous learning was implemented in the courses above, range from 2 to 10 meetings. Students were required to complete the learning modules for each session: reading materials, teaching video, assignment, quiz, and discussion forum. The questionnaires were divided into four sections. The first was about the data of the courses taken. The second was about the effectiveness of each element of asynchronous learning. The questions were categorized into six variables as follow:

Table 2. Operationalization of variables

\begin{tabular}{|c|c|c|c|c|c|}
\hline No & Variables & Code & $\begin{array}{c}\text { Operational } \\
\text { Definition }\end{array}$ & & Indicators \\
\hline 1 & $\begin{array}{l}\text { Effectivity of } \\
\text { materials }\end{array}$ & EM & $\begin{array}{l}\text { The degree to } \\
\text { which the } \\
\text { material is } \\
\text { absorbed/unde } \\
\text { rstood by } \\
\text { students. }\end{array}$ & $\begin{array}{l}\text { EM2 } \\
\text { EM3 } \\
\text { EM4 }\end{array}$ & $\begin{array}{l}\text { The amount of the materials given is } \\
\text { appropriate to the number of course } \\
\text { credits. } \\
\text { The materials accommodate the course } \\
\text { requirements } \\
\text { The materials enrich my knowledge. } \\
\text { The portion between theory and practice } \\
\text { is proportional }\end{array}$ \\
\hline 2 & $\begin{array}{l}\text { Effectivity of } \\
\text { videos }\end{array}$ & $\mathrm{EV}$ & $\begin{array}{l}\text { The degree to } \\
\text { which videos } \\
\text { help students } \\
\text { understand the } \\
\text { subjects }\end{array}$ & $\begin{array}{l}\text { EV1 } \\
\text { EV2 }\end{array}$ & $\begin{array}{l}\text { The videos help me understand the } \\
\text { subject } \\
\text { The video duration is proportional }\end{array}$ \\
\hline 3 & $\begin{array}{l}\text { Effectivity of } \\
\text { assignments }\end{array}$ & EA & $\begin{array}{l}\text { The degree to } \\
\text { which } \\
\text { assignment } \\
\text { helps students } \\
\text { understand the } \\
\text { subjects }\end{array}$ & $\begin{array}{l}\text { EA1 } \\
\text { EA2 } \\
\text { EA3 }\end{array}$ & $\begin{array}{l}\text { The assignments help me understand the } \\
\text { subjects } \\
\text { I have enough time to do the assignments } \\
\text { The scores are given based on a clear } \\
\text { scoring rubric. }\end{array}$ \\
\hline
\end{tabular}


IJCAS-Vol.8 No.2, December 2021

p-ISSN 2339-191X | e-ISSN 2406-9760

\begin{tabular}{|c|c|c|c|c|c|}
\hline 4 & $\begin{array}{l}\text { Effectivity of } \\
\text { quizzes }\end{array}$ & EQ & $\begin{array}{l}\text { The degree to } \\
\text { which quizzes } \\
\text { help students } \\
\text { understand the } \\
\text { subjects }\end{array}$ & $\begin{array}{l}\text { EQ1 } \\
\text { EQ2 }\end{array}$ & $\begin{array}{l}\text { The quizzes help me to understand the } \\
\text { subjects } \\
\text { I have enough time to do the quizzes }\end{array}$ \\
\hline 5 & $\begin{array}{l}\text { Effectivity of } \\
\text { interaction }\end{array}$ & EI & $\begin{array}{l}\text { The degree to } \\
\text { which the } \\
\text { forum helps } \\
\text { students } \\
\text { actively } \\
\text { participate in } \\
\text { the discussion. }\end{array}$ & $\begin{array}{l}\text { EI1 } \\
\text { EI2 } \\
\text { EI3 } \\
\text { EI4 }\end{array}$ & $\begin{array}{l}\text { I have the opportunity to discuss with } \\
\text { other students actively. } \\
\text { I have the opportunity to discuss with the } \\
\text { lecturer actively. } \\
\text { the interaction between lecturer and } \\
\text { students is active. } \\
\text { The interaction among students is active. }\end{array}$ \\
\hline 6 & $\begin{array}{l}\text { Effectivity of } \\
\text { duration }\end{array}$ & ED & $\begin{array}{l}\text { The degree to } \\
\text { which } \\
\text { asynchronous } \\
\text { learning } \\
\text { duration helps } \\
\text { students } \\
\text { understand the } \\
\text { subjects }\end{array}$ & ED1 & $\begin{array}{l}\text { The learning duration is appropriate to } \\
\text { the number of course credits. }\end{array}$ \\
\hline
\end{tabular}

The third section was about the effectivity of overall asynchronous learning. It was defined as the degree to which asynchronous learning helps students understand the material. This was categorized as EO. The last section was dedicated to students' feedback for asynchronous learning.

\section{RESULTS}

\section{A. Descriptive measurement}

Three hundred fourteen respondents participated in the survey. However, 19 were invalid. Thus, two hundred ninety-five respondents were counted in this survey. Two hundred two students were in courses that combined theory and practice, categorized as Group 1. At the same time, 93 students were in theorybased courses.

The first step in this research is to find the descriptive analysis using SPSS. Based on statistic data processing, the result is as follow:

Table 3. Mean of Effectivity Variables

\begin{tabular}{llccc}
\hline No & \multicolumn{1}{c}{ Variable } & $\begin{array}{c}\text { Group 1 } \\
\text { (Theory+Practice) }\end{array}$ & $\begin{array}{c}\text { Group 2 } \\
\text { (Theory) }\end{array}$ & $\begin{array}{c}\text { Significance } \\
\text { of difference }\end{array}$ \\
\hline EM & Effectivity of materials & 3,7809 & 3,828 & .572 \\
EV & Effectivity of videos & 3,9183 & 3,9355 & .664 \\
EA & Effectivity of & 3,7195 & 3,767 & .393 \\
& assignments & 3,6485 & 3,6989 & .611 \\
EQ & Effectivity of quizzes & 3,3391 & 3,293 & .525 \\
EI & Effectivity of interaction & & &
\end{tabular}




\begin{tabular}{llccc} 
ED & Effectivity of duration & 3,78 & 3,86 & .286 \\
EO & Effectivity of overall & 3,6898 & 3,6846 & .214 \\
& asynchronous learning & & \\
\hline
\end{tabular}

\section{B. Measurement result of effectivity of asynchronous learning}

The next step after getting the result of the descriptive analysis is to find the interval evaluation. The study uses a 5-point Likert scale with 1 as the lowest and 5 as the highest scores. The formula to get the interval is as follow:

$$
\begin{aligned}
\text { Interval } & =(\text { highest score }- \text { lowest score }) / \text { highest score } \\
& =(5-1) / 5 \\
& =\mathbf{0 . 8}
\end{aligned}
$$

Table 4. Interval table

\begin{tabular}{lc}
\hline Interval & Meaning \\
\hline $1.0-1.8$ & Very Ineffective \\
$1.8-2.6$ & Ineffective \\
$2.6-3.4$ & Moderate \\
$3.4-4.2$ & Effective \\
$4.2-5$ & Very effective \\
\hline
\end{tabular}

Based on the data shown in the table above, we can see that the means for EM, EV, EA, EQ, ED, and EO for both groups are between 3,6485 and 3,9355. From here, it can be concluded that the effectiveness of the materials, videos, assignments, quizzes, and duration are effective for theory-based and theory and practice-based courses. It means asynchronous learning is effective to be applied in both types of courses.

For EI, the means is 3,3391 for group 1 (theory and practice-based courses) and 3,293 for group 2 (theory-based courses). It indicates that the effectiveness of interaction in theory-based and theory and practice-based courses is moderate.

\section{B.1. The measurement result of significance of the difference between groups 1 and 2}

For a variable to be considered significantly different, the score should be < 0.05 . However, from table 2 the significant difference for all variables is above 0.05 . It can be concluded that asynchronous learning for theory-based and practicebased courses is not significantly different in terms of effectivity of materials, videos, assignments, quizzes, interaction, duration, and students' perception toward asynchronous learning. 


\section{DISCUSSION}

As we can see from the findings, the result of this study is positive. The data analysis shows that asynchronous learning is effective in both theory-based and theory and practice-based courses. There is no significant difference between both types of courses regarding the analyzed components of asynchronous learning: materials, videos, assignments, quizzes, interaction, duration, and students' perception.

\section{Effectivity of materials}

The means for the effectivity of material for theory and practice-based courses is 3,7809, whereas for theory-based courses is 3,828. From the result, it can be concluded that materials for both types, of course, are effective. The materials developed by the Film Department follow the course requirements and credits. The materials also enrich students' knowledge of the subjects taught. The result also indicates that the portion between theory and practice in the course is proportional. Although the result is effective, some participants prefer to have practice supervised directly by the teacher because they are unsure whether they are doing it right. Besides, they also want the teacher to give them instant feedback toward the practice, which couldn't be done if it is in asynchronous mode.

\section{Effectivity of videos}

The means for this variable is the highest among all variables tested. The means for theory and practice-based courses is 3,9183, whereas for theory-based courses is 3,9355 . It indicates that the videos provided in the asynchronous are effective. The videos help participants understand the subjects. Furthermore, the duration is proportional. The duration of the video is around 8-10 minutes. If the topic discussed is long, it will be divided into two or more videos. The length follows the suggestion from PEDATI.

\section{Effectivity of assignments}

For this variable, the means for theory and practice-based courses is 3,7195. The means for theory is 3,767. This variable is also considered effective. The assignments help participants to understand the subjects taught. Participants have enough time to do the assignments. For asynchronous mode, participants have five days to do and submit the assignment to the LMS. Some participants suggest that it will be better if the teacher reminds students of the deadline of the assignments so that they can submit the assignments on time. 


\section{Effectivity of quizzes}

For theory and practice-based courses, the means is 3,6485, whereas for the theory-based course is 3,6989. The variable result is effective. Participants agree that the quizzes help them to understand the subjects. They also have enough time to do the quizzes. The time allocated for doing a quiz is 10 minutes. Each quiz consists of 10-15 multiple choice questions related to the subject discussed.

\section{Effectivity of interaction}

The means for this variable is moderate: 3,3391 for the theory and practicebased courses and 3,293 for the theory. The feedback from the participants also supports the result. They mention that the interaction is not like the regular face-toface meeting. Some students feel demotivated because they don't experience direct interaction. To accommodate this, activities that can motivate students' interaction can be applied. For example, online debate, in which students may choose a side on certain topics and share their thoughts. They are motivated to challenge or dispute the opponents' ideas. Topics for such activity need to be carefully selected. It will be better if the issues are about hot topics on related discussed subjects. Participants of this study also suggest opening a $\mathrm{Q}$ and $\mathrm{A}$ forum with lecturers. They want lecturers to be more active in the discussion and give them quick responses. Another suggestion is to open a challenge forum for students to test a new method/way of exercising - for example, a challenge to experiment on "bokeh" cinematography. Bokeh is the aesthetic quality of an image's out-of-focus blur (Hicks and Nisperos 2000). The result of the experiment is to be shared and discussed in the forum.

\section{Effectivity of duration}

The result of this variable is effective. The means for theory and practicebased courses is 3,78 , and the theory-based courses is 3,86 . The participants agree that the learning duration is appropriate to the number of course credits. The duration has been carefully calculated and checked by the E-learning team. The instructional designer will analyze the lesson plans and ensure that every required item follows the regulation before production.

\section{Effectivity of overall asynchronous learning}

The means for this variable in theory and practice-based courses is 3,6898 , whereas in theory-based is 3,6846 . In general, students have a positive perception of asynchronous learning. Based on the feedback, they like asynchronous learning because they can manage their schedule to learn. This flexibility gives them the freedom to work at their pace of learning. However, some also mention that they miss the face-to-face class meeting because they like to socialize with other friends. 


\section{CONCLUSION}

This study shows that the asynchronous learning applied in the chosen courses is effective. The asynchronous follows PEDATI principles that require the learning modules to have teaching videos, materials, assignments, quizzes, and discussion forums. The modules must be adjusted to the learning duration designed in the lesson plans. Despite the positive result, this study has some weaknesses. First, it does not differentiate the gender of the participants. Thus, we cannot see whether there is a different result between male and female respondents. Second, the study should be conducted separately. One is for theory-based courses only. The other is for the theory and practice courses. Thus, students who have taken both types of courses can give independent comments for each course. Further research on confirming that the effectiveness of the discussed variables has adversely affected asynchronous learning needs to be done. Exploring more on how to improve asynchronous learning might open up new ways of reaching out to students.

\section{REFERENCES [Times New Roman 14, bold]}

Annita, A. (2020). Teaching Film in New Normal Era at Film Department, Universitas Multimedia Nusantara. International Journal of Creative and Arts Studies, 7(2). https://doi.org/10.24821/ijcas.v7i2.4650

Bao, W. (2020). COVID -19 and online teaching in higher education: A case study of Peking University. Human Behavior and Emerging Technologies, 2(2), 113-115. https://doi.org/10.1002/hbe2.191

Chaeruman, U. A. (2017). PEDATI Model Desain Sistem Pembelajaran Blended.

Giatman, M., Siswati, S., \& Basri, I. Y. (2020). Online Learning Quality Control in the Pandemic Covid-19 Era in Indonesia. 2, 168-175. https://doi.org/10.15294/jne.v6i2.25594

Kasar, A. B., Reddy, M., \& Wagh, R. (2021). Current Situation of Education field due to Corona Virus Disease 19. http://www.paideumajournal.com

McBrien, J. L., Jones, P., \& Cheng, R. (2009). Virtual spaces: Employing a synchronous online classroom to facilitate student engagement in online learning. International Review of Research in Open and Distance Learning, 10(3). https://doi.org/10.19173/irrodl.v10i3.605

Murat, M., \& Bonacini, L. (2020). Coronavirus pandemic, remote learning and education inequalities (No. 679). http://hdl.handle.net/10419/224765

Onyema, E. M., Eucheria, N. C., Obafemi, F. A., Sen, S., Atonye, F. G., Sharma, A., \& Alsayed, A. O. (2020). Impact of Coronavirus Pandemic on Education. Journal of Education and Practice. https://doi.org/10.7176/jep/11-13-12

Rajhans, V., Memon, U., Patil, V., \& Goyal, A. (2020). Impact of COVID-19 on academic activities and way forward in Indian Optometry. Journal of 
Optometry, 13(4), 216-226. https://doi.org/10.1016/j.optom.2020.06.002 Saputro, B., \& Susilowati, A. T. (2019). Effectiveness of Learning Management System (LMS) on In-Network Learning System (SPADA) based on scientific. Journal for the Education of Gifted Young Scientists, 7(3). https://doi.org/10.17478/jegys.606029

Schwartz, A. M., Wilson, J. M., Boden, S. D., Moore, T. J., Bradbury, T. L., \& Fletcher, N. D. (2020). Managing resident workforce and education during the COVID-19 pandemic evolving strategies and lessons learned. JBJS Open Access, 5(2). https://doi.org/10.2106/JBJS.OA.20.00045

UNESCO. (2020). Education: From disruption to recovery. https://en.unesco.org/covid19/educationresponse 